\title{
Addressing the long- and short-run effects of climate change on major food crops production in Turkey
}

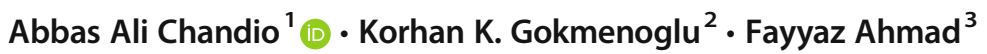 \\ Received: 11 March 2021 / Accepted: 6 May 2021 / Published online: 14 May 2021 \\ (C) The Author(s), under exclusive licence to Springer-Verlag GmbH Germany, part of Springer Nature 2021
}

\begin{abstract}
This study assessed the long-run (LR) and short-run (SR) impacts of climatic and non-climatic factors, i.e., $\mathrm{CO}_{2}$ emissions $\left(\mathrm{CO}_{2} \mathrm{e}\right)$, average level of temperature (ALT), average level of precipitation (ALP), area harvested of wheat and rice crops (AHW and (AHR), domestic credit (DCR), and agricultural labor (ALB) on wheat and rice production (WP and RP) in Turkey by using annual time series data ranging from 1980 to 2016 and by employing several econometric techniques. The autoregressive distributed lag-bounds (ARDL) approach and the Johansen and Juselius cointegration (JJC) test confirmed a valid long-term connection among underlying variables. The estimation results from the ARDL model reveal that climatic factors such as $\mathrm{CO}_{2}$ emissions and temperature adversely affected wheat production in the long run as well as in the short run, whereas precipitation positively improved wheat production in both periods. Further results indicate that non-climatic factors like area harvested of wheat and domestic credit positively and significantly enhanced wheat production in the long run and short run. Similarly, $\mathrm{CO}_{2}$ emissions also adversely affected rice production in both periods, while temperature and precipitation positively contributed towards rice production in both cases. In addition, area harvested of rice positively and significantly boosted rice production in the long run as well as in the short run, while domestic credit negatively influenced rice production in the long run but in the short run positively improved rice production. Additionally, the outcomes of the VECM Granger Causality for both rice and wheat production confirm that both climatic and non-climatic variables have a strong influence on the production of both crops. This study found that climate change has a deleterious influence on both wheat and rice production; therefore, the study suggests that temperature-resistant varieties of both crops should be developed and introduced by agricultural research institutions. In addition to this, up-to-date information is more needed related to climate change, and in the farming communities, it should be provided by agricultural extension workers.
\end{abstract}

Keywords Climate change $\cdot$ Wheat production $\cdot$ Rice production $\cdot$ ARDL approach · Turkey

\section{Introduction}

Food security has been under the threat of several interconnected factors such as population growth, environmental

Responsible Editor: Philippe Garrigues

Abbas Ali Chandio

alichandio@sicau.edu.cn

1 College of Economics, Sichuan Agricultural University, Chengdu 611130, China

2 Department of Banking and Finance, Eastern Mediterranean University, North Cyprus via Mersin, 10 Famagusta, Turkey

3 School of Economics, Lanzhou University, Lanzhou 730000, China problems, and land degradation. It is estimated that the everincreasing world population will reach approximately 10 billion by 2100 (Chandio et al. 2020a). Developing countries have played a major role in this increase. The high growth rates of many developing countries and their high food income elasticity are expected to put significant pressure on the global food market for the next few decades (Blandford and Hassapoyannes 2018). To meet global demand, primary crop supply must be increased by at least $70 \%$ by 2050 (Godfray et al. 2010). However, there are many obstacles to increasing the production of the agriculture sector to meet this demand. Shrinkage of the arable land at a catastrophic rate (Hawkesford et al. 2013) and climate change (Adzawla et al. 2019; Arunrat and Pumijumnong 2015) are two prominent factors that hinder agricultural production and hence threaten 
food security (Tripathi et al. 2016). To mitigate the adverse consequences of environmental problems and lessen the vulnerability of the agriculture sector, the formulation of the adaption strategies and potential solutions are vital (Wang et al. 2018). For this purpose, in this study, we investigated the effects of $\mathrm{CO}_{2}$ emissions, average temperature, and average precipitation on major food crops (wheat and rice) production of Turkey to have a better understanding of the impacts of environmental problems and accordingly to propose policy alternatives.

Environmental problems that endanger the sustainability and protection of livelihoods have been among the most critical issues of this century (Xie et al. 2018). The unprecedented atmospheric concentration of $\mathrm{CO}_{2}$ emissions has caused great concern due to its role in global climate change (IPCC 2013). The average surface temperature is expected to increase by $0.6^{\circ} \mathrm{C}$ over the next three decades and, by the end of the century, to be $4.8^{\circ} \mathrm{C}$ higher than its pre-industrial age levels (IPCC 2014). Global warming is expected to trigger a series of undesirable occurrences, such as increased frequency and intensity of nature-based disasters, unpredicted changes in rainfall patterns and timing of rainy seasons, erratic climatic factors, severe heat waves, sea-level rise, surface water runoff, water scarcity, decreased soil moisture, desertification, and glacier retreats (Pickson et al. 2020; Praveen and Sharma 2019; Tesfahunegn and Gebru 2019). These developments will have devastating effects on world economies and may eventually cause socio-economic turmoil.

The agriculture sector has played a major role in the development of national economies of both developed and developing countries by providing raw material for other industries, contributing to the development of non-agricultural sectors, and providing foreign exchange earnings as an internationally traded commodity. The harmony between agricultural and other sectors promotes the economic growth of the countries (Ahmad et al. 2020). A significant portion of the population of many countries live in rural areas, and agriculture and related sectors are the dominant sources of income for these families. Furthermore, the agricultural sector prevents potential food calamities by ensuring the uninterrupted provision of the food supply. Hence, any problem in the agricultural sector first and the most severely hits the lower income-families and increases inequality and regional disparity. Due to the reasons stated, the problems that may occur in the agricultural sector will have significant repercussions on the economy and society.

Although all major industries are susceptible to climate change, the agriculture sector is the one that has the highest vulnerability (Guntukula 2020). Many plants are sensitive to temperature changes; hence, global warming will have destructive effects on agricultural production (Appiah et al. 2018). Higher mean temperature might cause a reduction in the yields of food and non-food crops by changing the time to maturity that is needed by a plant (Hatfield and Prueger 2015).
It is argued that a $1{ }^{\circ} \mathrm{C}$ increase in the mean seasonal temperature might reduce the yield up to $10 \%$ (You et al. 2009). The availability of water for irrigation (Bhardwaj et al. 2018), water quality, and rainfall patterns (Aryal et al. 2019) are severely affected by climate change, thus causing an additional adverse impact on agricultural productivity. Environmental problems affect fertilizer supply, photosynthesis and transpiration rates, pathogens, sowing, harvest dates, erosion and soil fertility, pest attacks, and disease (Lemi and Hailu 2019). The deleterious effects of climate change on the agriculture sector of developing countries have intensified in the last several decades (Ahmed et al. 2018; Chandio et al. 2020b). It is predicted that most African as well Asian countries will be suffering from severe food insecurity by the end of the 2080s (Wang et al. 2018; Zewdie 2014).

Turkey can be characterized as a developing country with comparatively high growth rates. The energy demand of the country has been mostly satisfied by fossil fuels (TUBA 2020). Furthermore, Turkey has been experiencing a rapid and widespread urbanization process. All these factors increase carbon dioxide $\left(\mathrm{CO}_{2}\right)$ emissions and contribute to environmental degradation in Turkey. Turkey is located in the Mediterranean basin, which has semi-arid and arid regions; hence, along with the other countries in this region, Turkey is expected to be adversely affected by the problems related to changes in climate (IPCC 2007). The extreme temperature increases that occur in the Mediterranean basin in both spring and summer seasons pose a great threat to agricultural productivity in the region. The number of hot days and average level of temperatures in Turkey are increasing over the past few decades; 2018 and 2019 were recorded as the second and fourth warmest years of the last half-century (MGM 2019). An increase of $2-3{ }^{\circ} \mathrm{C}$ is expected in the temperature values in the country until 2040 (Demircan et al. 2017). Mediterranean basin has been under drought risk since the 1970s, as well. Particularly in the Aegean, Mediterranean, and Southeast Anatolia regions of Turkey, drought is getting more severe (TUBA 2020). Only 20\% of the country's total 24 MHs of agricultural land can be irrigated, and $70 \%$ of the water resources are used for this purpose (Dellal and Unuvar 2019). The agricultural production of the country is mostly dependent on precipitation, which makes the country very sensitive to irrigation water scarcity and rainfall shortages.

Wheat historically has been an essential source of nutrition in Turkey. Turkey is among the top ten largest wheat producers in the world. Wheat production, which was 8 million tons in 1970 , has increased by an average of $2.56 \%$ annually and reached about 19 million tons as of 2019 (TRMAF 2019). Figure 1 indicates a mixed trend in wheat production. However, in 1989, a significant decrease can be observed. Overall, the variations in production are constant during the whole period. Wheat production is mainly dependent on rainfall conditions, which makes this product vulnerable to 
Fig. 1 The trend of the area and wheat production in Turkey. Data source: FAO (2016)

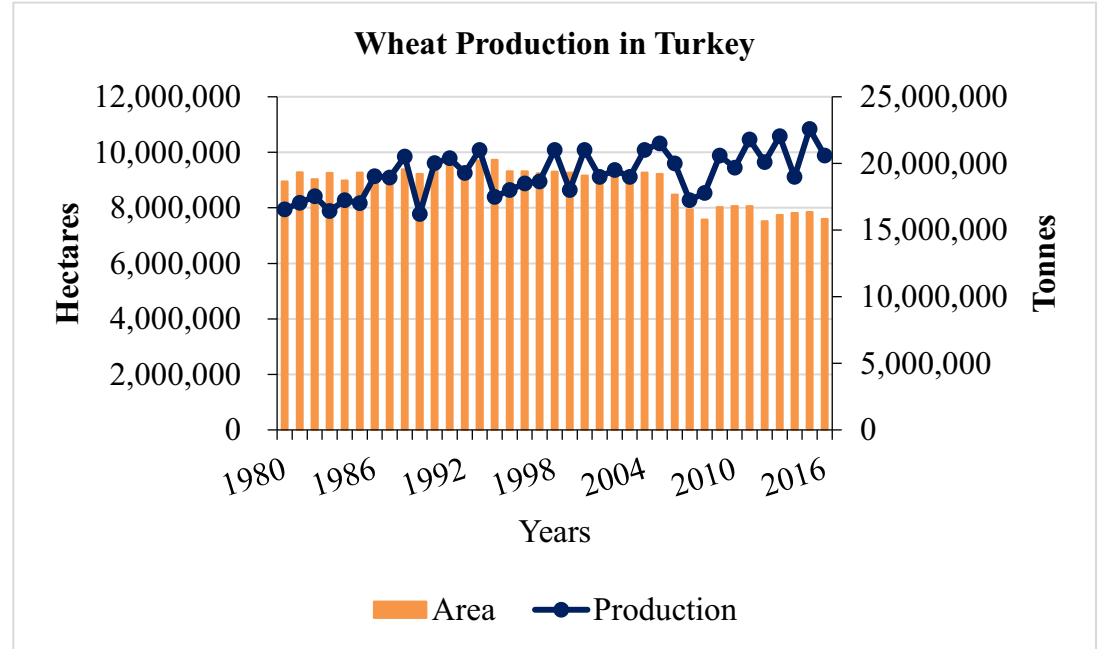

climatic conditions and causes significant fluctuations in output from year to year (Dudu and Çakmak 2018).

Since 1970, along with the increase in paddy cultivation areas, rice production of Turkey tends to increase. In 2019, paddy production reached about one million tons (TUIK 2020). The rice production cannot meet the increasing domestic consumption in Turkey; having a self-sufficiency rate of around $70 \%$, the country imports a significant amount of rice every year. Figure 2 describes the trend of rice production. From 1981 to 2001, the curve is relatively flat and increases afterward. Besides, for the last decade, there has been substantial variability in paddy/rice production. The biggest obstacle in rice production is insufficient irrigation, and irregular rain patterns in the spring and summer months negatively affect the harvest.

The geographic location and the high level of fossil fuel dependency of Turkey make its agricultural sector sensitive to environmental pollution and related problems. For the food security of the country and sustainable development, adaptive responses and the application of sound policies are essential. To provide a basis for policymaking, we investigate the effect of $\mathrm{CO}_{2}$ emissions, mean level of temperature, and mean level of precipitation on two major crop yields of Turkey from 1980 to 2016. We use the ARDL approach, which has been widely used for environmental studies, ${ }^{1}$ considering the stochastic properties of the variables in our empirical model.

In our empirical model, we also consider the potential impact of harvested area for each crop, domestic credit, and agriculture labor force. The labor force has been considered by the economic growth theories as among the most fundamental long-run determinants of economic growth (Ahmad et al. 2020). This variable has been employed in the

${ }^{1}$ For more information, see Ahmad et. al. (2021). agricultural production literature as well. Many studies have reported a positive significant long run and/or causal relationship between the agricultural labor force and agricultural production (Epaphra and Mwakalasya 2017; Pickson et al. 2020; Sial et al. 2011). As an indispensable ingredient of agricultural production, the cultivated area variable has been included in the empirical models of previous research. It is expected that more land dedicated to harvesting leads to higher agricultural production. The significant positive effect of this variable on the output of agricultural products has been confirmed by the literature (Ahsan et al. 2020; Hussain 2012). The agricultural sector requires credit to finance its primary ingredients, such as fertilizers, pesticides, seeds, and livestock, for modernization and commercialization (Rehman et al. 2017), and to enhance technical efficiency, productivity, and increase profitability (Bahşi and Çetin 2020). Hence, the role of agricultural credit in agricultural production has been investigated and documented by previous research (Ahmad 2011; Akmal et al. 2012; Chandio et al. 2020a). Recently, although there is many published high-quality research that investigates the relationship between environmental degradation, climate change, and environmental production, they do not take into account the role of credit and labor force (Asumadu-Sarkodie and Owusu 2017; Rehman et al. 2020; Rehman et al. 2021).

\section{Literature review}

Environmental pollution and resulting climate change have been of great global concern for the last several decades, and many studies have evaluated their determinants and potential effects. However, in line with our basic research question, we limit our literature review to the impact of climate change on the agriculture sector and then, more specifically, its impact on 
Fig. 2 The trend of the area and rice production in Turkey. Data source: FAO (2016)

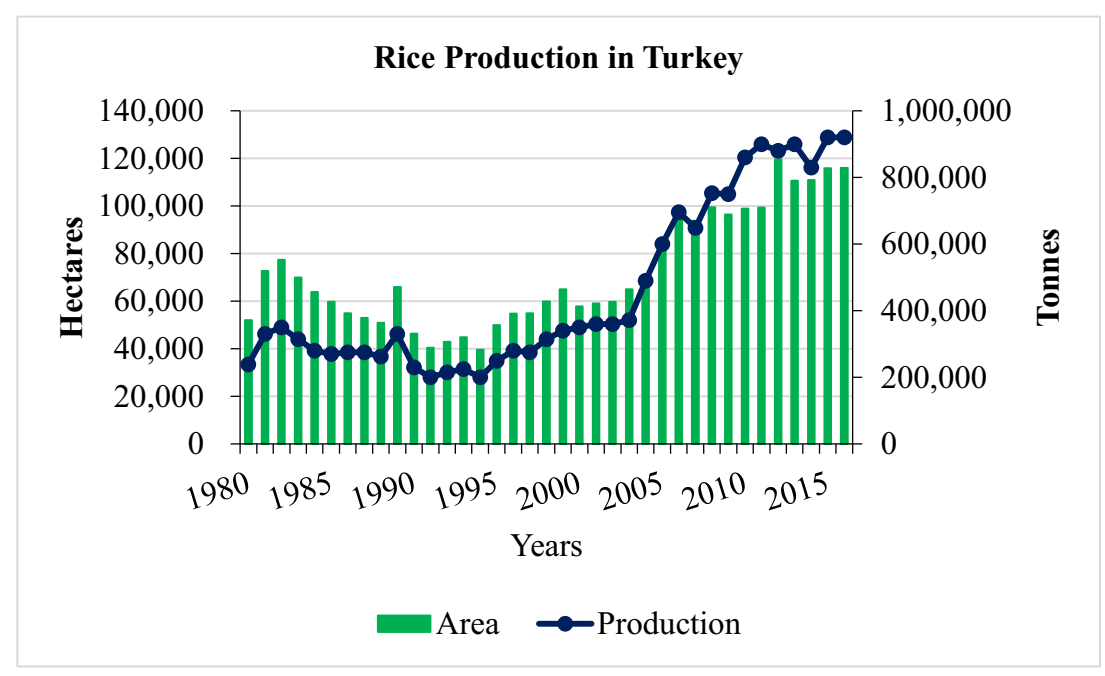

wheat and rice production. The direct and most drastic effect of greenhouse gases (GHG) emissions is on the environment. The detrimental effects of the atmospheric concentration of the GHG, such as an increase in the average temperature (Rosenzweig et al. 2014); a change in precipitation patterns (Zhao et al. 2017); more frequent floods, windstorms, famines, and droughts (Ullah et al. 2016); and loss of land and water resources (Ali et al. 2017), have been reported by many recent studies. Agriculture is the most vulnerable sector to these developments; hence, the effect of climatic events on this sector has attracted broad attention and is studied by many empirical studies. Also, the disruption of the agricultural systems by COVID-19 poses new challenges on all dimensions of food security (Devereux et al. 2020) and endangers food availability and food access. This development creates additional difficulties, especially for the most vulnerable people (United Nations 2020b) who live in developing countries (The United Nations System Standing Committee on Nutrition 2020), and necessitates the urgent need for resolutely executed actions (Rasul 2021). The aforementioned problems have increased the importance of appropriate agricultural policies and led to many recent studies (Rivera-Ferre et al. 2021; Ayyildiz and Erdal 2021).

This literature can be classified according to their methodological approaches: crop modeling (production function) approach, mathematical programming (Adams et al. 1999), Ricardian approach (Mendelsohn et al. 1994), and econometric approach. Although the econometric approach is relatively more recent, it has been the most rapidly developing field. Following the pioneering paper of Auffhammer et al. (2006), who assessed the effect of climate changes on crop yield, many researchers have employed time series and panel data models to investigate this relationship. In this study, we followed this tradition and used time-series econometrics methods to examine our main research question.
There is an abundance of evidence on the regional, national, and global scale that environmental problems and climate changes have detrimental effects on agricultural production (Tesfahunegn and Gebru 2019). Also, many studies have confirmed the significant impact of $\mathrm{CO}_{2}$ emissions on agricultural output (Traore et al. 2020). Climate change might have direct (e.g., temperature increase and change in rainfall patterns) and indirect effects (e.g., growth of diseases that cause higher costs and make crop management more difficult) (Qureshi et al. 2016; Zaied and Cheikh 2015) on agricultural production. Besides, climate change will make the arable land less fertile for agricultural production. These problems would have widescale implications and repercussions. A decrease in agricultural output becomes a potential danger for food security, increases the pressure on scarce resources, causes land abandonment of the farmers due to loss of income (Attiaoui and Boufateh 2019), and possibly creates socio-economic and political distresses.

Wheat is the number one domesticated crop, and it has been the most widely produced, harvested, demanded, and consumed cereal crop for many regions of the world because of its adoption to a wide range of climatic conditions and moisture levels (Ahsan et al. 2020). Although literature pays special attention to the influence of climate changes on wheat production because of its importance, empirical findings are inconclusive and sometimes uncertain. Many researchers have claimed that climate change is detrimental to wheat production. For example, in France, it was predicted that wheat yield would decrease up to $12.9 \%$ in the medium term, and this decrease would become more severe at the end of the century (Gammans et al. 2017). However, some other researchers claimed that climate change increases wheat yield for some regions of the world, like north-central China (Zhang and Huang 2013). According to Kersebaum and Nendel (2014), regional heterogeneity is the reason for these diverse findings. Sultana et al. (2009) provided empirical evidence for this 
explanation. Their results showed that increases in temperature cause a reduction in the yield of wheat for both arid and semi-arid areas; however, the effect is just the opposite for the wet zone of Pakistan. Similarly, there are inconclusive findings regarding the impact of precipitation on wheat production. Although rainfall is generally beneficial for crops, more rain during the growth period of wheat decreases the yield (Zhai et al. 2017). Recently, Ullah et al. (2019) reported that climate and rainfall changes harm the yield of what in both arid and semi-arid regions. These inconclusive findings imply that for a specific region, the influence of precipitation and climate conditions on wheat production is an open question and should be empirically investigated.

It is being the world's third most important agricultural product considering the amount of production, an essential commodity for international trade, and a staple for more than 3 billion people make rice a widely investigated research topic. Rice is quite sensitive to climatic conditions and environmental issues. Studies show that $\mathrm{CO}_{2}$ emissions lead to higher photosynthetic rates, water loss, and ultimately increases the yield (Chandio et al. 2020b; Mahato 2014). However, rising in temperature would cause a reduction in the yield of rice because above $35{ }^{\circ} \mathrm{C}$ temperature harms pollen viability and spikelet sterility (Tesfahunegn and Gebru 2019). Most of the studies stated that higher temperature and a decline in precipitation cause a reduction in both crop quality and productivity (Babel et al. 2011; Boansi 2017; Boonwichai et al. 2019; Shrestha et al. 2017).

Although climate change and resulting environmental problems are universal phenomena, the vulnerability of each country depends on its adaptive capacity and its specific conditions (Guiteras 2009). For example, some studies argued that in the short and medium run, some regions such as northern Europe even might take advantage of climate change and increase their crop yield (Isoard 2011). Therefore, each country and even region should be investigated as unique cases. Developing countries are more vulnerable to climate-related effects due to their low adaptive capacity (Aryal et al. 2019; Hossain et al. 2019; Iqbal et al. 2016), lower ability to alleviate the adverse effects (Dubey and Sharma 2018; Perez et al. 2019), and inadequate resources. However, most studies have focused on developed countries, and developing countries have taken less attention. Besides, in a region where the average temperature is already close to the tolerance level of the crops planted, the impact of climate change is expected to be more severe. For these reasons, developing countries located in arid or semi-arid areas, such as Turkey, is of particular importance in the investigation of climate-related factors on the agricultural sector.

Researchers have studied the potential impacts of climate change on the agriculture sector of Turkey by using different approaches. Cline (2007) estimated that an increase in the average level of temperature and a decrease in the level of precipitation would harm the agricultural productivity of Turkey considerably. Combining a crop water requirement model and an economy-wide model, Dudu and Çakmak (2018) investigated the effect of climate change on the Turkish economy. Their results show that the adverse impact of environmental problems would intensify in the second part of the century, which gives the country a chance to develop its adaptive strategies. Based on simulations, Özdoğan (2011) claimed that a higher concentration of $\mathrm{CO}_{2}$ emissions and related temperature and precipitation changes might reduce the winter wheat yield between 5 and $35 \%$ in northwestern Turkey. Based on these results, Özdoğan stressed the importance of taking necessary precautions, such as developing more resilient cultivars to alleviate the harmful effects of environmental degradation. In their recent study, Vanli et al. (2019), using farmer field-level data, confirmed previous research findings that ecological problems have a detrimental effect on agriculture. Using a paired biophysical and economic analysis, Dellal et al. (2011) demonstrated that climate change is expected to decrease yield for five major crops (i.e., wheat, barley, corn, sunflower, and cotton) up to $10.1 \%$ in Turkey. Dellal and Unuvar (2019) expanded the study of Dellal et al. (2011) and affirmed the negative influence of climate change on the supply of the main agricultural products of Turkey for the 2000-2016 period. The estimates based on Penman-Monteith and BlaneyCriddle formulas pointed out that yields would reduce, on average, $2-7 \%, 4-12 \%$, and $5-20 \%$ in 2020,2050 , and 2080, respectively.

The use of econometric models to assess the influence of climate change on agricultural production is more recent, and the number of such research is limited for the case of Turkey. Eruygur and Özokcu (2016) studied the influence of climaterelated variables on wheat production by using a panel data approach. Their long-term simulations verified that even under the best-case scenario, lower bound estimation implies a yield reduction. Dumrul and Kilicaslan (2017) used timeseries data that covers the 1961-2013 period to quantify the impact of climate change on the agricultural sector of Turkey. ARDL approach estimations reveal negatively effect of precipitation and temperature increase, respectively, on the agricultural output. Dogan and Karakas (2018) confirmed the effect of temperature and rainfall on the agricultural production of Turkey by employing panel data methods, including panel cointegration and panel dynamic ordinary least squares. The contribution of these studies to the formation of a substantial body of knowledge is undeniable. However, a limited number of econometric studies have not taken into account many factors, such as the financial aspect. In this research, we aim to fill this gap by providing a more comprehensive picture of the long-run and short-run impact of climate-related problems on the 
production of major food crops (i.e., wheat and rice) in Turkey from 1980 to 2016.

\section{Methodology}

\section{Data}

The current study used 37 years long annual time-series data of Turkey from 1980 to 2016. Data of wheat production, area harvested of wheat, rice production, and area harvested of rice are gathered from Food and Agriculture Organization (FAO) website (www.fao.org), while $\mathrm{CO}_{2}$ emission, temperature, precipitation, domestic credit, and agriculture labor are extracted from the World Bank (WB) (www.databank. worldbank.org). All considered study variables are converted into a logarithm form. Table 1 reports the data description, sources, and summary of descriptive statistics. In addition, Fig. 3 demonstrates the trend of all study variables.

\section{Econometric modeling}

This study uses the ARDL technique to evaluate the short- and long-run influences of climate conditions on major food crop production (i.e., wheat and rice) in Turkey. The ARDL approach developed by Pesaran et al. (2001) used with the help of unrestricted vector error correction model (VECM) to explore the long-way connection between wheat and rice production and climatic and non-climatic factors, namely carbon dioxide emissions, average temperature, average precipitation, area harvested of wheat crop, area harvested of rice crop, domestic credit, agriculture labor, respectively. The ARDL technique of cointegration has various advantages upon other cointegration techniques as follows:

- It can be employed regardless of whether considered variables are purely cointegrated at $\mathrm{I}(0)$, I( 1$)$, or the combination of both integration order (Pesaran et al. 2001)

- This approach is applicable for small sample properties (Haug, 2002).

- This method has estimated long-way and short-way cointegration relationship simultaneously.

This study scrutinizes the impact of both climatic and nonclimatic factors including $\mathrm{CO}_{2}$ emissions, average level of temperature, average level of precipitation, area harvested of wheat and rice crops, domestic credit, and agriculture labor on wheat and rice production by following the model specification of Ahmad et al. (2020); Ahsan et al. (2020); Chandio et al. (2020b); Janjua et al. (2014); Pickson et al. (2020), who also used above climatic and non-climatic dynamics in their model specification.

Table 1 Details of the study variables and descriptive statistical summary

\begin{tabular}{|c|c|c|c|c|c|c|c|c|c|}
\hline \multicolumn{2}{|l|}{ Variables } & Code & \multicolumn{6}{|c|}{ Description } & Sources \\
\hline \multicolumn{2}{|c|}{ Wheat production } & WP & \multicolumn{6}{|c|}{ Wheat production in tons } & FAO \\
\hline \multicolumn{2}{|c|}{ Area harvested of wheat } & AHW & \multicolumn{6}{|c|}{ Area harvested of wheat crop in hectares } & FAO \\
\hline \multicolumn{2}{|c|}{ Rice production } & $\mathrm{RP}$ & \multicolumn{6}{|c|}{ Rice production in tons } & FAO \\
\hline \multicolumn{2}{|c|}{ Area harvested of rice } & AHR & \multicolumn{6}{|c|}{ Area harvested of rice crop in hectares } & FAO \\
\hline \multicolumn{2}{|l|}{ Carbon dioxide } & $\mathrm{CO}_{2}$ & \multicolumn{6}{|c|}{$\mathrm{CO}_{2}$ emissions in $\mathrm{kt}$} & WB \\
\hline \multicolumn{2}{|l|}{ Temperature } & AT & \multicolumn{6}{|c|}{ Average annual temperature in ${ }^{\circ} \mathrm{C}$} & WB \\
\hline \multicolumn{2}{|l|}{ Precipitation } & AP & \multicolumn{6}{|c|}{ Average annual precipitation in $\mathrm{mm}$} & WB \\
\hline \multicolumn{2}{|l|}{ Domestic credit } & DCR & \multicolumn{6}{|c|}{ Domestic credit to private sector by banks ( $\%$ of GDP) } & WB \\
\hline \multirow{2}{*}{\multicolumn{2}{|c|}{ Agricultural labor }} & ALB & \multicolumn{6}{|c|}{ Percentage of rural population to total population } & WB \\
\hline & & & \multicolumn{6}{|c|}{ Statistical summary of the study variables } & \\
\hline & LWP & LAHW & LRP & LAHR & $\mathrm{LCO}_{2}$ & LAT & LAP & LDCR & LALB \\
\hline Mean & 16.7678 & 15.9954 & 12.9026 & 11.1359 & 12.1276 & 2.4384 & 3.8464 & 3.1387 & 3.6011 \\
\hline Median & 16.7616 & 16.0376 & 12.7367 & 11.0818 & 12.1898 & 2.4367 & 3.8726 & 2.9168 & 3.5917 \\
\hline Maximum & 16.9335 & 16.0913 & 13.7321 & 11.6924 & 12.8286 & 2.5882 & 4.0420 & 4.1856 & 4.0292 \\
\hline Minimum & 16.6018 & 15.8333 & 12.2060 & 10.5856 & 11.2353 & 2.2743 & 3.5911 & 2.6092 & 3.2529 \\
\hline Std. Dev. & 0.0899 & 0.0803 & 0.5201 & 0.3282 & 0.4527 & 0.0651 & 0.1189 & 0.4706 & 0.2169 \\
\hline Skewness & -0.1265 & -0.8900 & 0.4728 & 0.2103 & -0.3044 & 0.1801 & -0.4135 & 1.0725 & 0.2762 \\
\hline Kurtosis & 1.9946 & 2.2032 & 1.7130 & 1.8809 & 2.1196 & 3.2754 & 2.4609 & 2.8006 & 2.1688 \\
\hline Jarque-Bera & 1.6568 & 5.8642 & 3.9319 & 2.2036 & 1.7664 & 0.3172 & 1.5025 & 7.1557 & 1.5358 \\
\hline Probability & 0.4367 & 0.0532 & 0.1400 & 0.3322 & 0.4134 & 0.8533 & 0.4717 & 0.0279 & 0.4639 \\
\hline Observations & 37 & 37 & 37 & 37 & 37 & 37 & 37 & 37 & 37 \\
\hline
\end{tabular}



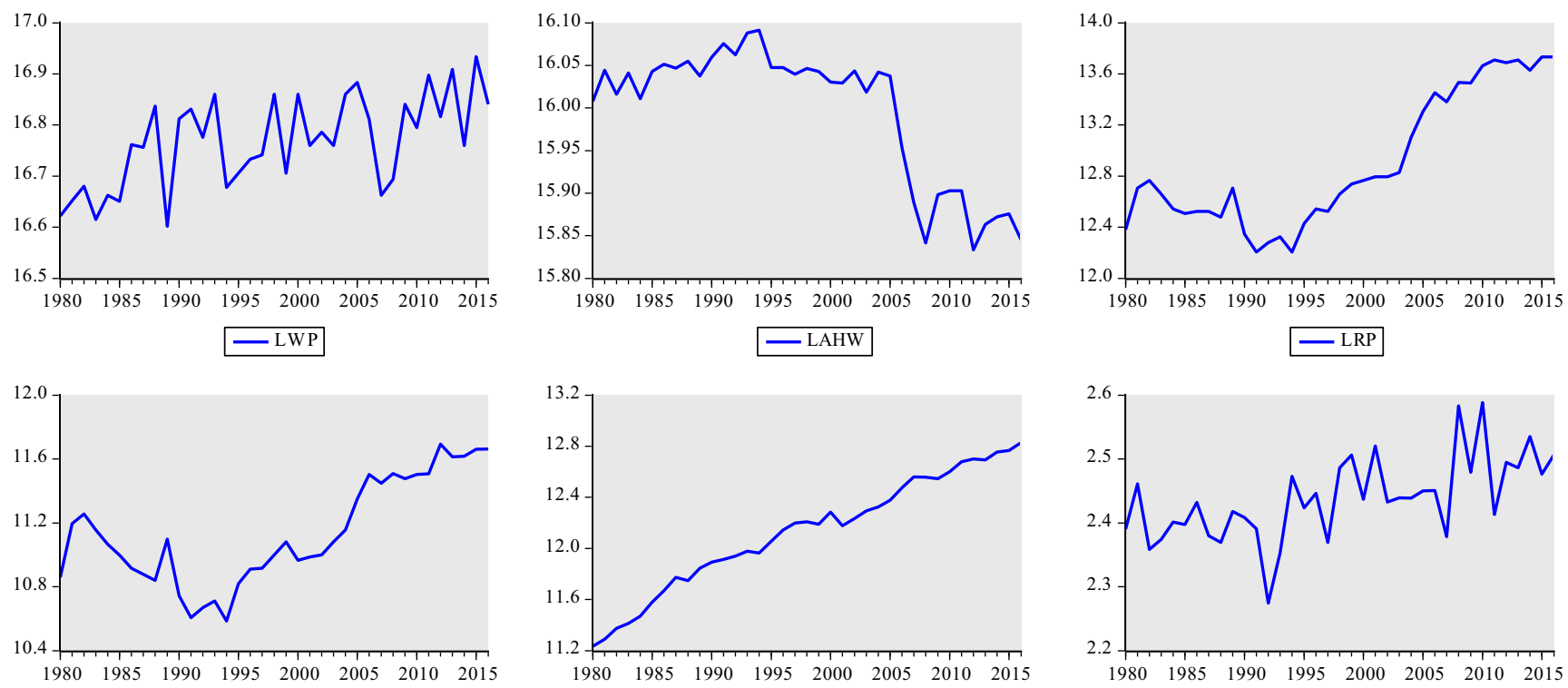

- LAHR
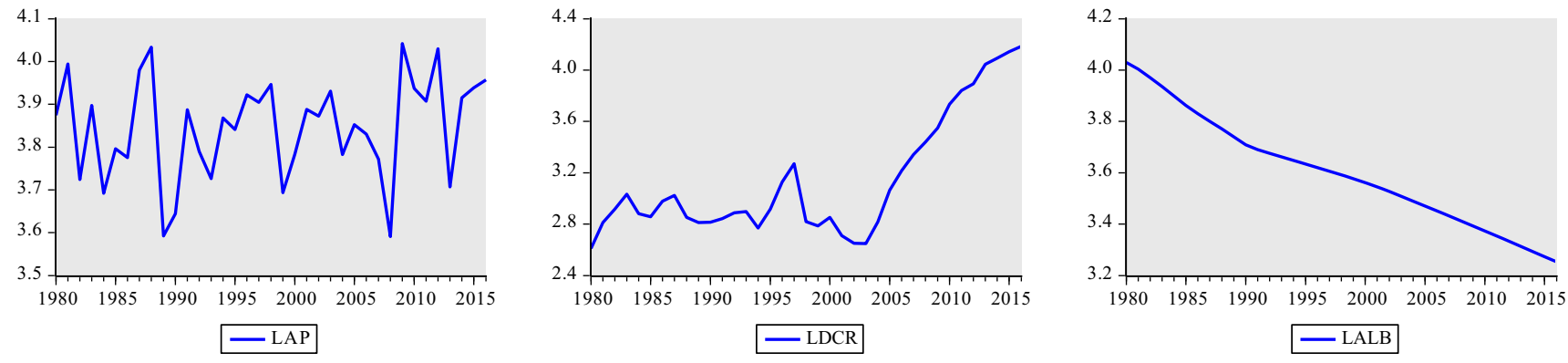

Fig. 3 The trend of the study variables. Legend: LWP, LAHW, LRP, LAHR, $\mathrm{LCO}_{2}$, LAT, LAP, LDCR, and LALB denote the natural logarithm of wheat production, area harvested of wheat crop, rice

production, area harvested of rice crop, carbon dioxide emissions, the mean level of temperature, the mean level of precipitation, domestic credit, and agriculture labor, respectively

Therefore, our sample models for our study are formulated as follows:

$$
\begin{aligned}
L W P_{t}= & \beta_{0}+\beta_{1} L C O_{2 t}+\beta_{2} L A T_{t}+\beta_{3} L A P_{t} \\
& +\beta_{4} L A H W_{t}+\beta_{5} L D C R_{t}+\beta_{6} L A L B_{t}+\varepsilon_{t}
\end{aligned}
$$

$$
\begin{aligned}
L R P_{t}= & \beta_{0}+\beta_{1} L C O_{2 t}+\beta_{2} L A T_{t}+\beta_{3} L A P_{t}+\beta_{4} L A H R_{t} \\
& +\beta_{5} L D C R_{t}+\beta_{6} L A L B_{t}+\varepsilon_{t}
\end{aligned}
$$

In Eq. (1), $L W P$ denotes the log of wheat production, $\mathrm{LCO}_{2}$ represents the $\log$ of $\mathrm{CO}_{2}$ emissions, $L A T$ is the log of average temperature, $L A P$ is the log of average precipitation, $L A H W$ is the log of area harvested of wheat crop, $L D C R$ is the log of domestic credit, $L A L B$ is the $\log$ of labor force, and $\varepsilon_{t}$ stands for the error term. In Eq. (2), $L R P$ represents the log of rice production, $L A H R$ is the log of area harvested of rice crop, and other variables we have discussed above.
The motive of the current study is to explore the short- and long-run effect of climate conditions on wheat and rice production, we can rewrite Eqs. (1) and (2) as long-way cointegrating of ARDL equations as follows:

$$
\begin{aligned}
\Delta L W P_{t}= & \lambda_{0}+\sum_{i=1}^{n} \lambda_{1} \Delta L W P_{t-i}+\sum_{i=1}^{n} \lambda_{2} \Delta L C O_{2 t-i} \\
& +\sum_{i=1}^{n} \lambda_{3} \Delta L A T_{t-i}+\sum_{i=1}^{n} \lambda_{4} \Delta L A P_{t-i} \\
& +\sum_{i=1}^{n} \lambda_{5} \Delta L A H W_{t-i}+\sum_{i=1}^{n} \lambda_{6} \Delta L D C R_{t-i} \\
& +\sum_{i=1}^{n} \lambda_{7} \Delta L A L B_{t-i}+\psi_{1} L W P_{t-1}+\psi_{2} L C O_{2 t-1} \\
& +\psi_{3} L A T_{t-1}+\psi_{4} L A P_{t-1}+\psi_{5} L A H W_{t-1} \\
& +\psi_{6} L D C R_{t-1}+\psi_{7} L A L B_{t-1} \\
& +\varepsilon_{t}
\end{aligned}
$$




$$
\begin{aligned}
\Delta L R P_{t}= & \phi_{0}+\sum_{i=1}^{n} \phi_{1} \Delta L R P_{t-i}+\sum_{i=1}^{n} \phi_{2} \Delta L C O_{2 t-i} \\
& +\sum_{i=1}^{n} \phi_{3} \Delta L A T_{t-i}+\sum_{i=1}^{n} \phi_{4} \Delta L A P_{t-i} \\
& +\sum_{i=1}^{n} \phi_{5} \Delta L A H R_{t-i}+\sum_{i=1}^{n} \phi_{6} \Delta L D C R_{t-i} \\
& +\sum_{i=1}^{n} \phi_{7} \Delta L A L B_{t-i}+\delta_{1} L R P_{t-1}+\delta_{2} L C O_{2 t-1} \\
& +\delta_{3} L A T_{t-1}+\delta_{4} L A P_{t-1}+\delta_{5} L A H R_{t-1} \\
& +\delta_{6} L D C R_{t-1}+\delta_{7} L A L B_{t-1} \\
& +\varepsilon_{t}
\end{aligned}
$$

where $\lambda_{1}$ and $\phi_{1}$ represent the coefficients of short-run dynamics for model 1 (wheat production) and model 2 (rice production), and $\psi_{1}$ and $\delta_{1}$ stand for the coefficients of long-run for models 1 and 2. $\Delta$ and $\varepsilon_{t}$ indicate the operator of first difference and the error term. To determine the long-way cointegration relationship between underlying variables, we regress Eqs. (3) and (4) by using ordinary least square (OLS) technique. In the present study, the ARDL bounds F-statistic is applied to test the null hypothesis of no longway cointegration connection between climatic and nonclimatic variables and wheat and rice production in Turkey against the alternative hypothesis demonstrating that there is long-way cointegration relationship between climatic and non-climatic variables and wheat and rice production. Thus, we formulated the following hypotheses are as follows:

$H_{1}: \psi_{1}=\psi_{2}=\psi_{3}=\psi_{4}=\psi_{5}=\psi_{6}=\psi_{7}$, this null hypothesis indicating that in the long-way wheat production, $\mathrm{CO}_{2}$ emissions, temperature, precipitation, area harvested of wheat crop, domestic credit, and agriculture labor are not cointegrated.

$H_{1}: \psi_{1} \neq \psi_{2} \neq \psi_{3} \neq \psi_{4} \neq \psi_{5} \neq \psi_{6} \neq \psi_{7}$, this alternative hypothesis showing that in the long-way wheat production, and climatic and non-climatic factors are cointegrated. $H_{2}: \delta_{1}=\delta_{2}=\delta_{3}=\delta_{4}=\delta_{5}=\delta_{6}=\delta_{7}$, this null hypothesis demonstrating that in the long-term rice production, $\mathrm{CO}_{2}$ emissions, temperature, precipitation, area harvested of rice crop, domestic credit, and agriculture labor are not cointegrated.

$H_{2}: \delta_{1} \neq \delta_{2} \neq \delta_{3} \neq \delta_{4} \neq \delta_{5} \neq \delta_{6} \neq \delta_{7}$, this alternative hypothesis suggesting that in the long-term rice production, and climatic and non-climatic factors are cointegrated.

After estimating the long-way relationship amid the studied variables, the next step is to explore the short-run correlation among the underlying variables based on Eqs. (3) and (4). The short-run cointegration of ARDL equations is expressed as follows:

$$
\begin{aligned}
\Delta L W P_{t}= & \lambda_{0}+\sum_{i=1}^{n} \lambda_{1} \Delta L W P_{t-i}+\sum_{i=1}^{n} \lambda_{2} \Delta L C O_{2 t-i} \\
& +\sum_{i=1}^{n} \lambda_{3} \Delta L A T_{t-i}+\sum_{i=1}^{n} \lambda_{4} \Delta L A P_{t-i} \\
& +\sum_{i=1}^{n} \lambda_{5} \Delta L A H W_{t-i}+\sum_{i=1}^{n} \lambda_{6} \Delta L D C R_{t-i} \\
& +\sum_{i=1}^{n} \lambda_{7} \Delta L A L B_{t-i}+\eta E C T_{t-1}+\varepsilon_{t}
\end{aligned}
$$

\begin{tabular}{|c|c|c|c|c|}
\hline \multirow[t]{2}{*}{ Variables } & \multicolumn{2}{|l|}{$\mathrm{ADF}$} & \multicolumn{2}{|l|}{ P-P } \\
\hline & $\zeta$ & $\Delta$ & $\zeta$ & $\Delta$ \\
\hline LWP & $-6.3100 * * *$ & $-11.2224 * * *$ & $-6.4324 * * *$ & $-25.8904 * * *$ \\
\hline LRP & -1.4991 & $-6.3486^{* * *}$ & -1.5096 & $-6.3559 * * *$ \\
\hline $\mathrm{LCO}_{2}$ & -2.6864 & $-6.8074 * * *$ & -2.6006 & $-6.9219 * * *$ \\
\hline LAT & $-6.4971 * * *$ & $-11.350 * * *$ & $-6.5800 * * *$ & $-22.0679 * * *$ \\
\hline LAP & $-6.1512 * * *$ & $-6.9571 * * *$ & $-8.6981 * * *$ & $-31.5100^{* * *}$ \\
\hline LAHW & -2.1083 & $-6.1748 * * *$ & -1.8740 & $-11.7976^{* * *}$ \\
\hline LAHR & -1.9257 & $-3.3392 * *$ & -1.6562 & $-6.9330 * * *$ \\
\hline LDCR & -2.0356 & $-7.8167 * * *$ & -1.8772 & $-8.3918 * * *$ \\
\hline LALB & $-4.6475 * * *$ & $-5.9989 * * *$ & $-4.2087 * *$ & $-7.5415 * * *$ \\
\hline
\end{tabular}

$$
\begin{aligned}
\Delta L R P_{t}= & \phi_{0}+\sum_{i=1}^{n} \phi_{1} \Delta L R P_{t-i}+\sum_{i=1}^{n} \phi_{2} \Delta L C O_{2 t-i} \\
& +\sum_{i=1}^{n} \phi_{3} \Delta L A T_{t-i}+\sum_{i=1}^{n} \phi_{4} \Delta L A P_{t-i} \\
& +\sum_{i=1}^{n} \phi_{5} \Delta L A H R_{t-i}+\sum_{i=1}^{n} \phi_{6} \Delta L D C R_{t-i} \\
& +\sum_{i=1}^{n} \phi_{7} \Delta L A L B_{t-i}+\eta E C T_{t-1}+\varepsilon_{t}
\end{aligned}
$$

\section{Results and discussions}

\section{Unit root test results}

The present study applied the Augmented Dickey-Fuller (ADF) test and Phillips-Perron (PP) test to inspect the stationary properties for long-term connection of the scrutinized variables. Table 2 reports the results of both unit root tests,

Table 2 Results of unit root tests

Note: $* * *$ and $* *$ show the significance at $1 \%$ and $5 \%$ levels, respectively 
indicating that wheat production, temperature, precipitation, and labor force are stationary at their level while rice production, $\mathrm{CO}_{2}$ emissions, area harvested of wheat crop, area harvested of rice crop, and domestic credit are not stationary at their level. After taking first difference, these considered variables are stationary and integrated. This means that the interested variables may reveal a valid long-term relationship. Thus, we can use the ARDL method to determine the longway relationship between considered variables.

\section{Cointegration test results}

Table 3 reports the estimated results of the ARDL bounds testing for long-term cointegration. Based on the results of both the ADF and PP unit root tests, we used the ARDL bounds testing to determine long-term cointegration relationship aimed variables. The results of the ARDL bound testing for models (I) and (II) reveal that the calculated F-statistic for the model (I) $F_{L W P}\left(L W P \mid L C O_{2}, L A T, L A P, L A H W, L D C R\right.$, $L A L B)$ value is 6.818 that is $\geq$ the values of upper bound at $1 \%$ significance level. It indicates that $\mathrm{CO}_{2}$ emissions, temperature, precipitation, area harvested of wheat crop, domestic credit, and labor force have a long-term cointegration relationship with wheat production. Further results show that the

Table 3 ARDL cointegration results for models (I) and (II)

\begin{tabular}{lcc}
\hline Function & F-statistic & \\
\hline$F_{L W P}\left(L W P \mid L C O_{2}, L A T, L A P, L A H W, L D C R, L A L B\right)$ & $6.8183^{* * * *}$ & \\
Critical value bounds & & \\
Significance & $\mathrm{I}(0)$ & $\mathrm{I}(1)$ \\
$10 \%$ & 2.53 & 3.59 \\
$5 \%$ & 2.87 & 4.00 \\
$1 \%$ & 3.60 & 4.90 \\
Diagnostic tests & & \\
$\mathrm{R}^{2}$ & 0.6388 & \\
Adj-R & \\
F-statistic & 0.5184 & \\
Prob(F-statistic) & 5.3058 & \\
$F_{L R P}\left(L R P \mid L C O_{2}, L A T, L A P, L A H R, L D C R, L A L B\right)$ & $3.3835^{*}$ & \\
Critical value bounds & & \\
Significance & $\mathrm{I}(0)$ & $\mathrm{I}(1)$ \\
$10 \%$ & 2.12 & 3.23 \\
$5 \%$ & 2.45 & 3.61 \\
$1 \%$ & 3.15 & 4.43 \\
Diagnostic tests & & \\
$\mathrm{R}^{2}$ & 0.0003 & \\
Adj-R & & \\
F-statistic & 0.9103 & \\
Prob(F-statistic) & 0.8596 & \\
\hline
\end{tabular}

Note: $* * *$ and $*$ show the significance at $1 \%$ and $10 \%$ levels, respectively calculated F-statistic for model (II) $F_{L R P}\left(L R P \mid L C O_{2}, L A T\right.$, $L A P, L A H W, L D C R, L A L B)$ value is 3.383 , which is also $\geq$ the values of upper bound at $10 \%$ significance level. This means the existence of long-run association between rice production and other climatic and non-climatic factors such as $\mathrm{CO}_{2}$ emissions, temperature, precipitation, area harvested of rice crop, domestic credit, and labor force, respectively.

This study used the Johansen and Juselius cointegration (JJC) method to further verify the existence of long-term cointegration between wheat and rice production and climatic and control variables. The results of the Johansen and Juselius cointegration (JJC) technique for models (I) and (II) are reported in Table 4, confirming the long-term cointegration between $\mathrm{CO}_{2}$ emissions, temperature, precipitation, area harvested of wheat crop, domestic credit, labor force, and wheat production. In addition, this approach also verifies the existence of the long-run cointegration among rice production and climatic and control variables.

\section{Long- and short-run estimates for model (I)}

Table 5 reports the results of long- and short-run ARDL estimations. Figure 4 exhibits the summary of long-term estimates.

Results indicate that $\mathrm{CO}_{2}$ emissions have negative impact on wheat production in both long and short run. It means that $1 \%$ increase in the concentration of $\mathrm{CO}_{2}$ emissions in the atmosphere will lead to decrease wheat production by $0.03 \%$ and $0.40 \%$. The findings of $\mathrm{CO}_{2}$ emissions are strongly substantiated by Casemir and Diaw (2018). The GHG emissions are the major causes of changes in climate condition in Turkey and due to human activities including urbanization,

Table $4 \quad$ J-J cointegration test results models (I) and (II)

\begin{tabular}{|c|c|c|c|c|}
\hline \multicolumn{3}{|c|}{ Dependent variable: LWP } & \multicolumn{2}{|c|}{ Dependent variable: LRP } \\
\hline Hypothesis & TST & MST & TST & MST \\
\hline$r=\leq 0$ & $\begin{array}{c}198.1364 * * * \\
(0.000)\end{array}$ & $\begin{array}{c}72.2677 * * * \\
(0.0000)\end{array}$ & $\begin{array}{c}150.9128 * * * \\
(0.0006)\end{array}$ & $\begin{array}{c}48.6017 * * \\
(0.0274)\end{array}$ \\
\hline $\mathrm{r}=\leq 1$ & $\begin{array}{c}125.8687 * * * \\
(0.0001)\end{array}$ & $\begin{array}{c}46.3972 * * * \\
(0.0085)\end{array}$ & $\begin{array}{c}102.3111^{* *} \\
(0.0164)\end{array}$ & $\begin{array}{l}39.7948 \\
(0.0538)\end{array}$ \\
\hline$r=\leq 2$ & $\begin{array}{c}79.4715 * * * \\
(0.0070)\end{array}$ & $\begin{array}{l}29.3166 \\
(0.1591)\end{array}$ & $\begin{array}{l}62.5161 \\
(0.1664)\end{array}$ & $\begin{array}{l}28.5228 \\
(0.1904)\end{array}$ \\
\hline $\mathrm{r}=\leq 3$ & $\begin{array}{c}50.1548^{* *} \\
(0.0299)\end{array}$ & $\begin{array}{l}27.6750 \\
(0.0487)\end{array}$ & $\begin{array}{l}33.9933 \\
(0.5022)\end{array}$ & $\begin{array}{l}14.5869 \\
(0.7801)\end{array}$ \\
\hline$r=\leq 4$ & $\begin{array}{l}22.4797 \\
(0.2726)\end{array}$ & $\begin{array}{l}12.0986 \\
(0.5379)\end{array}$ & $\begin{array}{l}19.4064 \\
(0.4640)\end{array}$ & $\begin{array}{l}11.2367 \\
(0.6237)\end{array}$ \\
\hline $\mathrm{r}=\leq 5$ & $\begin{array}{l}10.3811 \\
(0.2525)\end{array}$ & $\begin{array}{l}10.3160 \\
(0.1920)\end{array}$ & $\begin{array}{l}8.16972 \\
(0.4474)\end{array}$ & $\begin{array}{c}8.1041 \\
(0.3682)\end{array}$ \\
\hline $\mathrm{r}=\leq 6$ & $\begin{array}{c}0.0650 \\
(0.7986)\end{array}$ & $\begin{array}{c}0.0650 \\
(0.7986)\end{array}$ & $\begin{array}{c}0.0656 \\
(0.7978)\end{array}$ & $\begin{array}{c}0.0656 \\
(0.7978)\end{array}$ \\
\hline
\end{tabular}

Note: $* * *$ and $* *$ show the significance at $1 \%$ and $5 \%$ levels, respectively 
Table 5 Long- and short-run results based on ARDL method for model (I)

\begin{tabular}{|c|c|c|c|c|}
\hline Variables & Coefficient & Std. Error & $\begin{array}{l}\text { t- } \\
\text { statistic }\end{array}$ & Prob. \\
\hline
\end{tabular}

\begin{tabular}{|c|c|c|c|c|}
\hline \multicolumn{5}{|c|}{ Long-run estimates } \\
\hline \multicolumn{5}{|c|}{ Dependent variable: LWP } \\
\hline $\mathrm{LCO}_{2}$ & -0.0360 & 0.2318 & -0.1556 & 0.8775 \\
\hline LAT & $-0.2928^{*}$ & 0.1657 & -1.7668 & 0.0886 \\
\hline LAP & 0.0656 & 0.0742 & 0.8845 & 0.3842 \\
\hline LAHW & $0.7133 * *$ & 0.2986 & 2.3887 & 0.0242 \\
\hline LDCR & $0.0768 *$ & 0.0433 & 1.7721 & 0.0877 \\
\hline LALB & -0.1939 & 0.6471 & -0.2996 & 0.7667 \\
\hline $\mathrm{C}$ & 6.5749 & 8.2407 & 0.7978 & 0.4319 \\
\hline \multicolumn{5}{|c|}{ Short-run dynamics } \\
\hline $\operatorname{DLWP}(-1)$ & -0.3231 & 0.1552 & -2.0814 & 0.0470 \\
\hline $\mathrm{DLCO}_{2}$ & -0.4059 & 0.2955 & -1.3733 & 0.1809 \\
\hline $\mathrm{DLCO}_{2}(-1)$ & 0.3582 & 0.2827 & 1.2669 & 0.2160 \\
\hline DLAT & $-0.3874 *$ & 0.2177 & -1.7797 & 0.0864 \\
\hline DLAP & 0.0869 & 0.0991 & 0.8763 & 0.3886 \\
\hline DLAHW & $0.9438 * *$ & 0.3870 & 2.4385 & 0.0216 \\
\hline DLDCR & $0.1016^{*}$ & 0.0561 & 1.8089 & 0.0816 \\
\hline DLALB & -0.2566 & 0.8615 & -0.2978 & 0.7681 \\
\hline CointEq $(-1)$ & $-1.3231 * * *$ & 0.1552 & -8.5222 & 0.0000 \\
\hline $\mathrm{R}^{2}$ & 0.6524 & & & \\
\hline Adjusted $\mathrm{R}^{2}$ & 0.5365 & & & \\
\hline F-statistic & 5.6317 & & & \\
\hline Prob(F-statistic) & 0.0002 & & & \\
\hline Diagnostic tests & F-statistic & Prob. & & \\
\hline$\chi^{2} A R C H$ & 1.6423 & 0.2087 & & \\
\hline$\chi^{2} N O R M A L$ & 2.3209 & 0.3130 & & \\
\hline$\chi^{2}$ RESET & 0.2031 & 0.8406 & & \\
\hline$\chi^{2}$ SERIAL & 0.6123 & 0.5500 & & \\
\hline
\end{tabular}

Note: $* * * * *$, and $*$ show the significance at $1 \%, 5 \%$, and $10 \%$ levels, respectively transportation, non-renewable energy consumption, and deforestation, respectively.

Likewise, negative and significant coefficients of temperature both in the long and short run show that the rising level of temperature in Turkey has an adverse influence on wheat production. A decrease in wheat production leads to reduce growth of agricultural sector and create the challenge for food security in the country. This results implies that $1 \%$ increase in the mean level of temperature will decrease wheat production by $0.29 \%$ and $0.38 \%$. Our results related to temperature are consistent with the outcomes of previous research works of Pickson et al. (2020) and Sossou et al. (2019), who reported that temperature has negative impacts on cereal production. Further results reveal that precipitation has positive impact on wheat production in both cases. It implies that $1 \%$ increase in precipitation level will increase wheat production by $0.06 \%$ and $0.08 \%$. The findings of precipitation are strongly substantiated by Ahmad et al. (2020) and Zaied and Cheikh (2015), who found that precipitation positively improved crop production.

In addition, other important factors such as area harvested and domestic credit have significantly positive influence on wheat production in the long and short run. One percent increase in area harvested and domestic credit will enhance wheat production by $0.71 \%, 0.94 \%, 0.07 \%$, and $0.10 \%$ in both cases, respectively. These results are comparable with the findings of prior studies (Bashir et al. 2010; Chandio et al. 2016; Janjua et al. 2014). Zakaria et al. (2019) reported that credit provided by financial sector has significantly positive effect on agricultural production in South Asian countries.

The results of all the diagnostics tests (see Table 5) are suggesting that the ARDL model is stable over given time period 1980-2016. Estimated $\mathrm{R}^{2}$ value is 0.652 , which indicates that $65.2 \%$ variation the wheat production is due to climatic and no climatic variables. The stability of the ARDL model is tested by CUSUM and CUSUM squares tests.
Fig. 4 The summary of long-run connection between the scrutinized variables

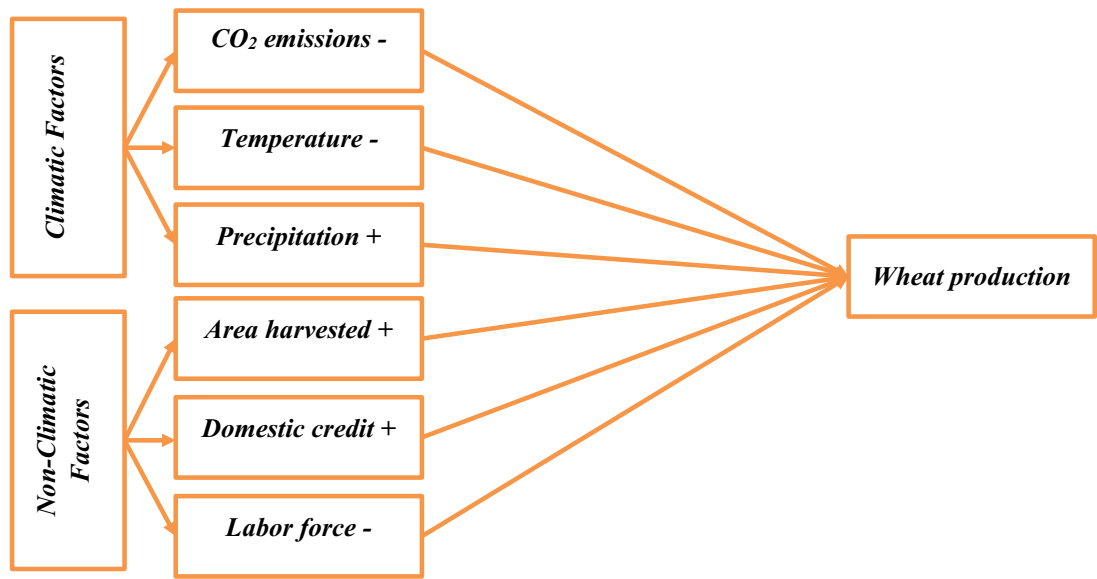


Table 6 VECM-based Ganger causality estimates for model (I)

Dependent variable Independent variables

\begin{tabular}{lccccccc}
\cline { 2 - 6 } & $\Delta \mathrm{LWP}$ & $\Delta \mathrm{LCO}_{2}$ & $\Delta \mathrm{LAT}$ & $\Delta \mathrm{LAP}$ & $\Delta \mathrm{LAHW}$ & $\Delta \mathrm{LDCR}$ & $\Delta \mathrm{LALB}$ \\
\hline$\Delta \mathrm{LWP}$ & ---- & 6.865592 & 0.327268 & $8.058720^{*}$ & $8.434627 *$ & 0.696638 & 3.157865 \\
$\Delta \mathrm{LCO}_{2}$ & $11.07584^{* *}$ & ---- & 4.543561 & 3.072949 & 5.246371 & 2.297613 & 1.897974 \\
$\Delta \mathrm{LAT}$ & $23.95553^{* * *}$ & $12.37109^{* *}$ & - & $15.40015 * * *$ & 6.908583 & 5.241930 & 1.509000 \\
$\Delta \mathrm{LAP}$ & $16.39830^{* * *}$ & 6.073060 & 1.683256 & ---- & 2.893583 & 2.103558 & 3.037906 \\
$\Delta \mathrm{LAHW}$ & $46.13111^{* * *}$ & $12.10711^{* *}$ & 1.060478 & 5.925616 & ---- & 1.944045 & 4.156997 \\
$\Delta \mathrm{LDCR}$ & $26.33264 * * *$ & $17.25945^{* * *}$ & 4.118271 & 5.216084 & 1.191704 & ---- & 2.426331 \\
$\Delta \mathrm{LALB}$ & $44.46411^{* * *}$ & $14.58020^{* * *}$ & $8.764486^{*}$ & 2.630665 & $10.27106^{* *}$ & 3.166100 & ---- \\
\hline
\end{tabular}

Note: $* * *, * *$, and $*$ show the significance at $1 \%, 5 \%$, and $10 \%$ levels, respectively

Results of both tests (see Figs. 5 and 6), indicating that there is no structural instability in the residuals of the model.

\section{Results of VECM-based Ganger causality tests for model (I)}

The results of the Granger causality under VECM taking wheat production as dependent variable are reported in Table 6 . The causal connection among wheat production, precipitation, and harvested area of wheat is significant showing the strong impact of these two variables on wheat production. The connection between $\mathrm{CO}_{2}$ emissions and wheat production is also indicating that more production affects the environment. Similarly, the link among temperature, wheat production $\mathrm{CO}_{2}$ emissions, and precipitations is significant. The wheat production and precipitation affects each other, and the harvested area as well as domestic credit is significantly connected with wheat production and $\mathrm{CO}_{2}$ emissions. Finally, wheat production, $\mathrm{CO}_{2}$ emissions, temperature, precipitation, and harvesting areas are connected with labor force. In short, the causal links are in the lines with previous results and indicate the significant link among each other. Therefore, both

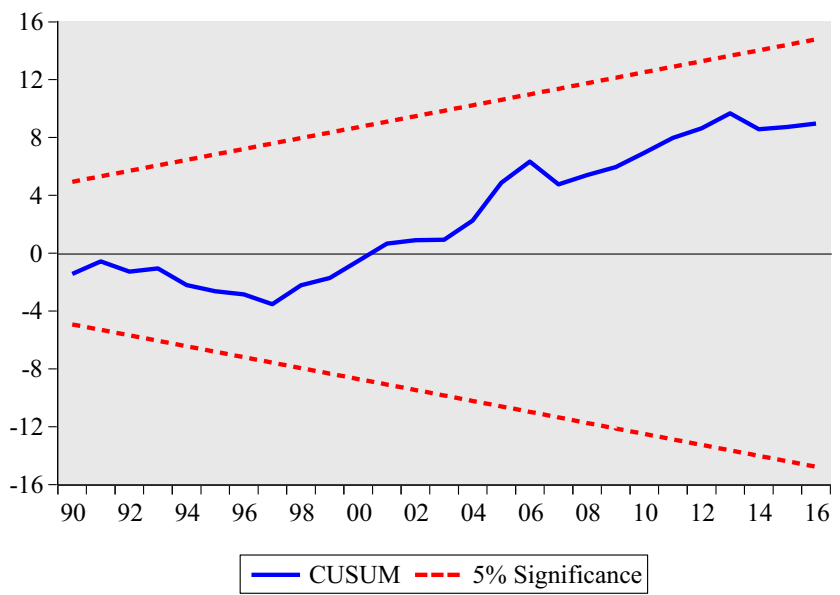

Fig. 5 Plot of cumulative sum test for model (I) climatic and non-climatic factors have a significant influence on the wheat production in Turkey.

\section{Long- and short-run estimates for model (II)}

Table 7 represents the long- and short-run results of the ARDL estimations. Figure 7 demonstrates the long-run summary of the underlying variables.

The estimated results reveal that the role of $\mathrm{CO}_{2}$ emissions is negative in both long- and short-run estimations. It means that $1 \%$ concentration of $\mathrm{CO}_{2}$ emissions increase, it will lead to decrease in rice production by $0.10 \%$ and $0.06 \%$. Our study results are in line with the outcomes of Chandio et al. (2020c) and Qureshi et al. (2016). In the context of Pakistan, Chandio et al. (2020b) explored that $\mathrm{CO}_{2}$ emissions positively affected production of rice in the long and short run. Most research works reported that climate change is negatively linked with agriculture around the globe. Raymundo et al. (2018) who found that high concentration of $\mathrm{CO}_{2}$ emissions in the atmosphere and an upsurge in the mean level of temperature negatively decreased tuber production. The outcomes further affirm that temperature has no adverse impact on rice

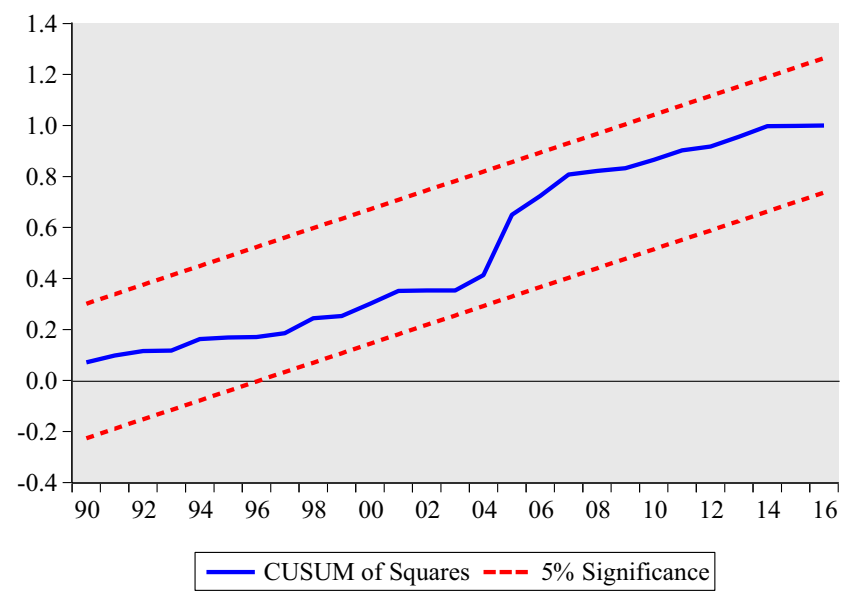

Fig. 6 Plot of cumulative sum of squares test for model (I) 
Table 7 Long- and short-run results based on ARDL method for model (II)

\begin{tabular}{lllll}
\hline Variables & Coefficient & Std. Error & $\begin{array}{l}\mathrm{t}- \\
\text { statistic }\end{array}$ & Prob. \\
\hline
\end{tabular}

\section{Long-run estimates}

Dependent variable: LRP

\begin{tabular}{|c|c|c|c|c|}
\hline $\mathrm{LCO}_{2}$ & -0.1025 & 0.4287 & -0.2392 & 0.8130 \\
\hline LAT & 0.9563 & 0.6174 & 1.5488 & 0.1351 \\
\hline LAP & 0.2020 & 0.2436 & 0.8293 & 0.4155 \\
\hline LAHR & $1.2069 * * *$ & 0.1158 & 10.4212 & 0.0000 \\
\hline LDCR & $-0.1443^{*}$ & 0.0824 & -1.7516 & 0.0932 \\
\hline LALB & -1.0143 & 0.8746 & -1.1597 & 0.2581 \\
\hline $\mathrm{C}$ & 1.6947 & 8.4470 & 0.2006 & 0.8428 \\
\hline \multicolumn{5}{|c|}{ Short-run dynamics } \\
\hline $\operatorname{DLRP}(-1)$ & $0.3871 * *$ & 0.1590 & 2.4339 & 0.0231 \\
\hline $\mathrm{DLCO}_{2}$ & -0.0628 & 0.2644 & -0.2377 & 0.8142 \\
\hline DLAT & 0.2853 & 0.2127 & 1.3411 & 0.1930 \\
\hline $\operatorname{DLAT}(-1)$ & 0.3006 & 0.2266 & 1.3267 & 0.1976 \\
\hline DLAP & -0.0724 & 0.1056 & -0.6856 & 0.4998 \\
\hline $\operatorname{DLAP}(-1)$ & $0.1962 *$ & 0.1024 & 1.9150 & 0.0680 \\
\hline DLAHR & $0.8688^{* * *}$ & 0.0993 & 8.7492 & 0.0000 \\
\hline $\operatorname{DLAHR}(-1)$ & -0.3026 & 0.2057 & -1.4710 & 0.1548 \\
\hline DLAHR(-2) & $0.1734 *$ & 0.0914 & 1.8974 & 0.0704 \\
\hline DLDCR & 0.1276 & 0.0882 & 1.4465 & 0.1615 \\
\hline $\operatorname{DLDCR}(-1)$ & -0.0123 & 0.1355 & -0.0913 & 0.9280 \\
\hline $\operatorname{DLDCR}(-2)$ & $-0.2037 * *$ & 0.0951 & -2.1410 & 0.0431 \\
\hline DLALB & -0.6215 & 0.5659 & -1.0983 & 0.2834 \\
\hline CointEq $(-1)$ & $-0.6128 * * *$ & 0.1590 & -3.8523 & 0.0008 \\
\hline $\mathrm{R}^{2}$ & 0.9924 & & & \\
\hline Adjusted $\mathrm{R}^{2}$ & 0.9881 & & & \\
\hline F-statistic & 231.7079 & & & \\
\hline Prob(F-statistic) & 0.0000 & & & \\
\hline Diagnostic tests & F-statistic & Prob. & & \\
\hline$\chi^{2} A R C H$ & 0.1340 & 0.7165 & & \\
\hline$\chi^{2} N O R M A L$ & 0.9631 & 0.6178 & & \\
\hline$\chi^{2} R E S E T$ & 0.9203 & 0.3674 & & \\
\hline$\chi^{2}$ SERIAL & 0.1132 & 0.8935 & & \\
\hline
\end{tabular}

Note: $* * * * *$, and $*$ show the significance at $1 \%, 5 \%$, and $10 \%$ levels, respectively

production in the long and short run. In the context of Bangladesh, Sarker et al. (2014) found that maximum level of temperature negatively declined rice production while minimum level of temperature positively improved rice production. Precipitation contributes positively to rice production in both estimations and it plays an imperative role in the growth of agriculture sector in Turkey. It implies that $1 \%$ increase in the level of precipitation will lead to improve rice production by $0.20 \%$ and $0.19 \%$ in the long and short run. The results agree with the research of (Ahmad et al. 2020; Ali et al. 2017;
Sossou et al. 2019; Zaied and Cheikh 2015). Khan et al. (2019) explored that the maximum level of temperature has a negative influence on maize production while rainfall positively improves maize production in Pakistan.

Area harvested is a leading factor in boosting up rice production in Turkey. It indicates that $1 \%$ increase in area harvested will lead to enhance the rice production by $1.20 \%$ and $0.86 \%$ in both periods. Domestic credit has a negative influence on rice production in the long run, while in the short run, it has a positive impact on it. These findings are parallel with the recent work of Afrin et al. (2017) and Omoregie et al. (2018).

The $\mathrm{R}^{2}$ value is 0.992 , demonstrating a $99.2 \%$ change in rice production by climatic and non-climatic variables. Further results of the diagnostics tests reveal that there is no indication of heteroscedasticity, serial correlation, and normality; thus, these tests suggested that the residuals are normally distributed in the model. The CUSUM and CUSUM squares tests affirmed the stability of the parameters of the ARDL model (see Figs. 8 and 9).

\section{Results of VECM-based Granger causality tests for model (II)}

Using rice production as dependent variable, the outcomes of Granger causality confirmed that harvested area and domestic credit significantly affect rice production. The causal connection is significant among $\mathrm{CO}_{2}$ emissions and many variables, including rice production, temperature, harvested area, and domestic credit. This indicates that these variables are significantly influencing the environment. The causal connection among temperature, rice production, $\mathrm{CO}_{2}$ emissions, harvested area, and domestic credit is also strongly significant. Similarly, rice production, $\mathrm{CO}_{2}$ emissions, harvested area, and labor force affect the level of precipitation. The causal link among harvested area, rice production, labor force, and domestic credit is significant, showing a strong link among these variables. Likewise, the relationship among domestic credit, rice production, and harvested area is strongly significant. Finally, rice production, $\mathrm{CO}_{2}$ emissions, harvested area domestic credit, and temperature significantly affect labor force. Overall, the VECM causality test verifies the significant connection of all variables and indicates that rice production is significantly linked with these variables (see Table 8).

\section{Conclusions}

This study examines the short- and long-run impacts of climatic and non-climatic factors, namely $\mathrm{CO}_{2}$ emissions, temperature, precipitation, area harvested of wheat and rice crops, domestic credit, and labor force on wheat and rice production in Turkey by using annual time-series data from the period of 
Fig. 7 The summary of long-run nexus between underlying variables

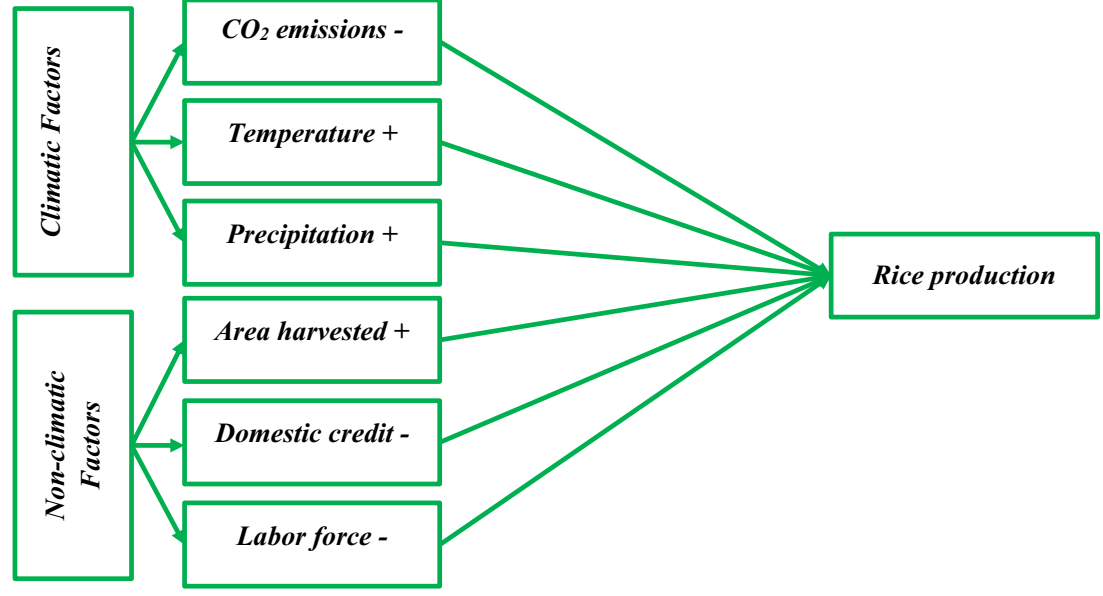

1980-2016. The ARDL bounds testing approach and Johansen and Juselius cointegration technique confirmed the valid long-way relationship amid underlying variables. Results reveal that climatic factors such as $\mathrm{CO}_{2}$ emissions and temperature negatively affected wheat production in the long run as well as in the short run, whereas precipitation contributed positively role towards wheat production in both periods. Further results show that non-climatic factors such as area harvested of wheat crop and domestic credit positively and significantly enhanced wheat production in the long run as well as in the short run. In addition, results indicate that $\mathrm{CO}_{2}$ emissions also negatively affected rice production in both cases. The temperature has no adverse effect on rice production, whereas precipitation improved rice production in the long run as well as in the short run. Area harvested of rice crop has a positive significant impact on rice production in both estimations, while domestic credit has a negative impact on rice production in the long run; however, in the short run, it has a positive impact on rice production. Additionally, the outcomes of the VECM Granger Causality for both rice and wheat production confirm that both climatic and non-climatic variables have a strong influence on the production of both

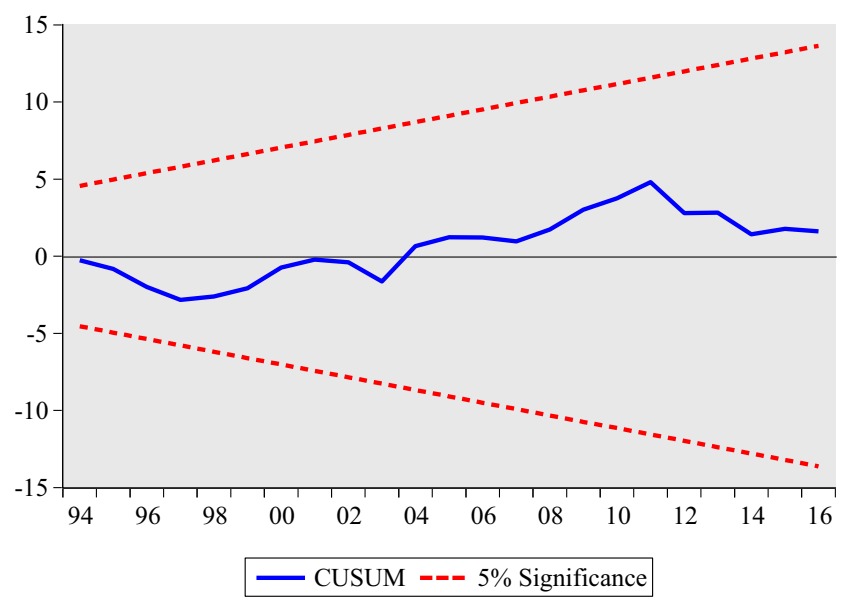

Fig. 8 Plot of cumulative sum test for model (II) crops. The causal connection is significant among $\mathrm{CO}_{2}$ emissions, harvested area, domestic credit, temperature, precipitation, and labor force for both wheat and rice production models. In Turkey, farming-households have less awareness about climate change; therefore, raising awareness among farming communities is more necessary on climate change by up-to-date information related to climate change by the extension workers and as well by policymakers. This study found that temperature has an adverse impact on wheat production; thus, temperature-resistant wheat varieties should be developed through agricultural research institutions in the country. Furthermore, credit plays a significant role in improving wheat and rice production; therefore, this study suggests that financial institutions should supply credit at low interest rate with easy installments to farming communities and farmers can get bountiful benefits from it to cope with climate change. Finally, climatic factors have negatively affected wheat production; thus, special consideration should be given to reduce $\mathrm{CO}_{2}$ emissions through modern technology application in wheat cultivation and harvest. This will help to improve environmental friendly wheat production in Turkey in the long run.

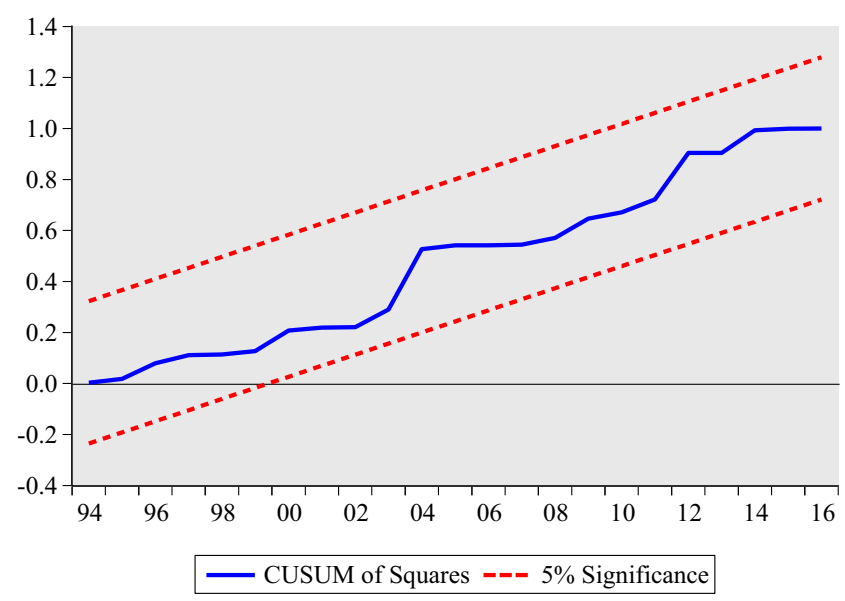

Fig. 9 The plot of the cumulative sum of squares test for model (II) 
Table 8 VECM-based Ganger causality estimates for model (II)

\begin{tabular}{|c|c|c|c|c|c|c|c|}
\hline \multirow[t]{2}{*}{ Dependent variable } & \multicolumn{6}{|c|}{ Independent variables } & \multirow[b]{2}{*}{$\Delta$ LALB } \\
\hline & $\Delta \mathrm{LRP}$ & $\Delta \mathrm{LCO}_{2}$ & $\Delta \mathrm{LAT}$ & $\Delta \mathrm{LAP}$ & $\triangle \mathrm{LAHR}$ & $\triangle \mathrm{LDCR}$ & \\
\hline$\Delta \mathrm{LRP}$ & ---- & 7.324474 & 5.860918 & 0.535112 & $30.79656^{* * * *}$ & $11.59843 * *$ & 3.995655 \\
\hline$\Delta \mathrm{LCO}_{2}$ & $45.43090 * * *$ & ---- & $19.20543 * * *$ & 0.586838 & $76.52828^{* * * *}$ & $9.019376^{*}$ & 5.528727 \\
\hline$\Delta \mathrm{LAT}$ & $120.0271 * * *$ & $14.91627 * * *$ & ----- & 6.757949 & $212.4700 * * *$ & $11.74884 * *$ & 5.634541 \\
\hline$\Delta \mathrm{LAP}$ & $219.8713 * * *$ & $20.72674 * * *$ & 7.718364 & ----- & $235.1209 * * *$ & 2.761835 & $24.53147 * * *$ \\
\hline$\Delta \mathrm{LAHR}$ & $129.7154 * * *$ & 3.897659 & 5.727644 & 0.252602 & ---- & $11.96568 * *$ & $19.67745^{* * *}$ \\
\hline$\triangle \mathrm{LDCR}$ & $261.8683 * * *$ & 5.844991 & 4.081571 & 5.756626 & $237.8346^{* * * *}$ & ----- & $27.06851 * * *$ \\
\hline$\Delta \mathrm{LALB}$ & $46.90249 * * *$ & $12.49421 * *$ & $23.35985 * * *$ & 0.774988 & $174.9386^{* * * *}$ & $9.856777 * *$ & ----- \\
\hline
\end{tabular}

Note: $* * *, * *$, and $*$ show the significance at $1 \%, 5 \%$, and $10 \%$ levels, respectively

\begin{abstract}
Abbreviations ARDL, autoregressive distributed-lag; ECM, error correction model; ADF, augmented Dickey-Fuller; P-P, Phillips-Perron; CUSUM, cumulative sum of recursive residuals; CUSUMSQ, cumulative sum of squares; JJC, Johansen and Juselius cointegration; OLS, ordinary least square; VECM, vector error correction model; WB, World Bank; GHGs, greenhouse gases; $\mathrm{CO} 2 \mathrm{e}$, carbon dioxide emission; FAO, Food and Agricultural Organization; IPCC, Intergovernmental Panel on Climate Change; TST, Trace Statistic Test; MST, Max-eigen-values Statistic Test
\end{abstract}

Author contribution Abbas Ali Chandio performed the conception and design of the study, data collection and analysis, drafting the work, and validation of the results.

Korhan K. Gokmenoglu has contributed in article writing, reviewed, and edited the manuscript.

Fayyaz Ahmad has contributed in data analysis and results interpretation.

Data availability The data will be available on request.

\section{Declarations}

Ethical approval Not applicable

Consent to participate Not applicable

Consent to publish Not applicable

Conflict of interest The authors declare no competing interests.

\section{References}

Adams RM, McCarl BA, Segerson K, Rosenzweig C, Bryant KJ, Dixon B.L., Conner R, Evenson RE, Ojima D, 1999. The economic effects of climate change on US agriculture. The impact of climate change on the United States Economy, 18-54

Adzawla W, Baumüller H, Donkoh SA, Serra R, 2019. Effects of climate change and livelihood diversification on the gendered productivity gap in Northern Ghana. Climate and Development, 1-13.

Afrin S, Haider MZ, Islam MS, Turvey C, Turvey C, 2017. Impact of financial inclusion on technical efficiency of paddy farmers in Bangladesh. Agricultural Finance Review, 00-00.
Ahmad N (2011) Impact of institutional credit on agricultural output. Pak Dev Rev 42:469-485

Ahmad S, Tariq M, Hussain T, Abbas Q, Elham H, Haider I, Li X (2020) Does Chinese FDI, climate change, and $\mathrm{CO} 2$ emissions stimulate agricultural productivity? An empirical evidence from Pakistan. Sustainability 12(18):7485

Ahmad M, Jabeen G, Irfan M, Ișık C, Rehman A (2021) Do inward foreign direct investment and economic development improve local environmental quality: aggregation bias puzzle. Environ Sci Pollut Res $1-21$

Ahmed I, Ur Rahman MH, Ahmed S, Hussain J, Ullah A, Judge J (2018) Assessing the impact of climate variability on maize using simulation modeling under semi-arid environment of Punjab, Pakistan. Environ Sci Pollut Res 25(28):28413-28430

Ahsan F, Chandio AA, Fang W, 2020. Climate change impacts on cereal crops production in Pakistan. International Journal of Climate Change Strategies and Management

Akmal N, Rehman B, Ali A, Shah H (2012) The impact of agriculture credit on growth in Pakistan. Asian Journal of Agriculture and Rural Development 2(393-2016-23882):579-583

Ali S, Liu Y, Ishaq M, Shah T, Ilyas A, Din IU (2017) Climate change and its impact on the yield of major food crops: evidence from Pakistan. Foods 6(6):39

Appiah K, Du J, Poku J (2018) Causal relationship between agricultural production and carbon dioxide emissions in selected emerging economies. Environ Sci Pollut Res 25(25):24764-24777

Arunrat N, Pumijumnong N (2015) The preliminary study of climate change impact on rice production and economic in Thailand. Asian Soc Sci 11(15):275-294

Aryal JP, Sapkota TB, Khurana R, Khatri-Chhetri A, Jat ML, 2019. Climate change and agriculture in South Asia: adaptation options in smallholder production systems. Environment, Development and Sustainability(3).

Asumadu-Sarkodie S, Owusu PA (2017) The causal nexus between carbon dioxide emissions and agricultural ecosystem - an econometric approach. Environ Sci Pollut Res 24(2):1608-1618

Attiaoui I, Boufateh T (2019) Impacts of climate change on cereal farming in Tunisia: a panel ARDL-PMG approach. Environ Sci Pollut Res 26(13):13334-13345

Auffhammer M, Ramanathan V, Vincent JR (2006) Integrated model shows that atmospheric brown clouds and greenhouse gases have reduced rice harvests in India. Proc Natl Acad Sci 103(52):19668 19672

Ayyildiz M, Erdal G (2021) The relationship between carbon dioxide emission and crop and livestock production indexes: a dynamic common correlated effects approach. Environ Sci Pollut Res 28(1):597-610 
Babel MS, Agarwal A, Swain DK, Herath S (2011) Evaluation of climate change impacts and adaptation measures for rice cultivation in Northeast Thailand. Clim Res 46(2):137-146

Bahşi N, Çetin E (2020) Determining of agricultural credit impact on agricultural production value in Turkey. Ciência Rural 50(11)

Bashir MK, Mehmood Y, Hassan S (2010) Impact of agricultural credit on productivity of wheat crop: evidence from Lahore, Punjab, Pakistan. Pakistan Journal of Agricultural ences 47(4):403-407

Bhardwaj A, Misra V, Mishra A, Wootten A, Boyles R, Bowden J, Terando AJ (2018) Downscaling future climate change projections over Puerto Rico using a non-hydrostatic atmospheric model. Clim Chang 147(1-2):133-147

Blandford, D., Hassapoyannes, K., 2018. The role of agriculture in global GHG mitigation.

Boansi D (2017) Effect of climatic and non-climatic factors on cassava yields in Togo: agricultural policy implications. Climate 5(2):28

Boonwichai S, Shrestha S, Babel MS, Weesakul S, Datta A (2019) Evaluation of climate change impacts and adaptation strategies on rainfed rice production in Songkhram River Basin, Thailand. Sci Total Environ 652:189-201

Casemir BH, Diaw A (2018) Analysis of climate change effect on agricultural production in Benin. Asian Journal of Agricultural Extension, Economics \& Sociology, pp 1-12

Chandio AA, Jiang Y, Joyo MA, Rehman A (2016) Impact of area under cultivation, water availability, credit disbursement, and fertilizer offtake on wheat production in Pakistan. Journal of Applied Environmental and Biological Sciences 6(10):10-18

Chandio AA, Jiang Y, Rauf A, Ahmad F, Amin W, Shehzad K (2020a) Assessment of formal credit and climate change impact on agricultural production in Pakistan: a time series ARDL modeling approach. Sustainability 12(13):5241

Chandio AA, Magsi H, Ozturk I (2020b) Examining the effects of climate change on rice production: case study of Pakistan. Environ Sci Pollut Res 27(8):7812-7822

Chandio AA, Ozturk I, Akram W, Ahmad F, Mirani AA (2020c) Empirical analysis of climate change factors affecting cereal yield: evidence from Turkey. Environ Sci Pollut Res:1-14

Cline WR, 2007. Global warming and agriculture: impact estimates by country. Peterson Institute.

Dellal I, Unuvar F (2019) Effect of climate change on food supply of Turkey. J Environ Prot Ecol 20(2):692-700

Dellal İ, McCarl BA, Butt T (2011) The economic assessment of climate change on Turkish agriculture. J Environ Prot Ecol 12(1):376-385

Demircan M, Gürkan H, Eskioğlu O, ARABACI H, Coșkun M (2017) Climate change projections for Turkey: three models and two scenarios. Türkiye Su Bilimleri ve Yönetimi Dergisi 1(1):22-43

Devereux S, Béné C, Hoddinott J (2020) Conceptualising COVID-19's impacts on household food security. Food Security 12(4):769-772

Dogan HG, Karakas G (2018) The effect of climatic factors on wheat yield in Turkey: a panel DOLS approach. Fresenius Environ Bull 27:4162-4168

Dubey SK, Sharma D (2018) Assessment of climate change impact on yield of major crops in the Banas River Basin, India. Sci Total Environ 635:10-19

Dudu H, Çakmak EH (2018) Climate change and agriculture: an integrated approach to evaluate economy-wide effects for Turkey. Clim Dev 10(3):275-288

Dumrul Y, Kilicaslan Z (2017) Economic impacts of climate change on agriculture: empirical evidence from ARDL approach for Turkey. Journal of Business Economics and Finance 6(4):336-347

Epaphra M, Mwakalasya A, 2017. Analysis of foreign direct investment, agricultural sector and economic growth in Tanzania, 8, 111-140

Eruygur O, Özokcu S (2016) Impacts of climate change on wheat yield in Turkey: a heterogeneous panel study. Ekonomik Yaklasim 27(101): 219-255
Gammans M, Mérel P, Ortiz-Bobea A (2017) Negative impacts of climate change on cereal yields: statistical evidence from France. Environ Res Lett 12(5):054007

Godfray HCJ, Beddington JR, Crute IR, Haddad L, Lawrence D, Muir JF, Pretty J, Robinson S, Thomas SM, Toulmin C (2010) Food security: the challenge of feeding 9 billion people. science 327 (5967):812-818

Guiteras R (2009) The impact of climate change on Indian agriculture. Manuscript, Department of Economics, University of Maryland, College Park, Maryland

Guntukula R (2020) Assessing the impact of climate change on Indian agriculture: evidence from major crop yields. J Public Aff 20(1): e2040

Hatfield JL, Prueger JH (2015) Temperature extremes: effect on plant growth and development. Weather and climate extremes 10:4-10

Hawkesford MJ, Araus JL, Park R, Calderini D, Miralles D, Shen T, Zhang J, Parry MA (2013) Prospects of doubling global wheat yields. Food and Energy Security 2(1):34-48

Hossain MS, Qian L, Arshad M, Shahid S, Fahad S, Akhter J, 2019. Climate change and crop farming in Bangladesh: an analysis of economic impacts. International Journal of Climate Change Strategies and Management

Hussain AH (2012) Impact of credit disbursement, area under cultivation, fertilizer consumption and water availability on rice production in Pakistan (1988-2010). Sarhad J Agric 28(1):95-101

IPCC, 2007. Summary for policymakers. In: Climate change 2007: synthesis report. [M]//Change. Contribution of Working Groups I, II and III to the Fourth Assessment Report of the Intergovernmental Panel on Climate Change; Cambridge University Press: London, England, 2007

IPCC (2013) Summary for Policymakers. In: Stocker TF, Qin D, Plattner GK, Tignor M, Allen SK, Boschung J, Nauels A, Xia Y, Bex V, Midgley PM (eds) Climate change 2013: the physical science basis. Contribution of Working Group to the Fifth Assessment Report of the Intergovernmental Panel on Climate Change. Cambridge University Press, Cambridge, United Kingdom and New York, NY, USA

IPCC (2014) Summary for Policymakers. In: Edenhofer O, PichsMadruga R, Sokona Y, Farahani E, Kadner S, Seyboth K, Adler A, Baum I, Brunner S, Eickemeier P, Kriemann B, Savolainen J, Schlömer S, von Stechow C, Zwickel T, Minx JC (eds) Climate change 2014: mitigation of climate change. Contribution of Working Group III to the Fifth Assessment Report of the Intergovernmental Panel on Climate Change. Cambridge University Press, Cambridge, United Kingdom and New York, NY, USA

Iqbal, M.A., Ping, Q., Abid, M., Syed, M.M.K., Rizwan, M., 2016. Assessing risk perceptions and attitude among cotton farmers: a case of Punjab province, Pakistan. International Journal of Disaster Risk Reduction, 68-74.

Isoard, S., 2011. Perspectives on adaptation to climate change in Europe, Climate change adaptation in developed nations. Springer, pp. 5168.

Janjua PZ, Samad G, Khan N (2014) Climate change and wheat production in Pakistan: an autoregressive distributed lag approach. NJAS Wageningen Journal of Life Sciences 68:13-19

Kersebaum K, Nendel C (2014) Site-specific impacts of climate change on wheat production across regions of Germany using different $\mathrm{CO} 2$ response functions. Eur J Agron 52:22-32

Khan A, Ali S, Shah SA, Khan A, Ullah R (2019) Impact of climate change on maize productivity in Khyber Pakhtunkhwa, Pakistan. Sarhad Journal of Agriculture 35(2):594-601

Lemi T, Hailu F (2019) Effects of climate change variability on agricultural productivity. International Journal of Environmental Sciences \& Natural Resources 17(1):10-13 
Mahato A (2014) Climate change and its impact on agriculture. Int J Sci Res Publ 4(4):1-6

Mendelsohn R, Nordhaus WD, Shaw D (1994) The impact of global warming on agriculture: a Ricardian analysis. Am Econ Rev:753771

MGM, 2019. Climate assessment, Ministry of Agriculture and Forestry, General Directorate of Meteorology, January 2020, Ankara

Omoregie K, Ikpesu F, Okpe AE (2018) Credit supply and rice output in Nigeria: empirical insight from vector error correction model approach. Int J Econ Financ Issues 8(5):68-74

Özdoğan M (2011) Modeling the impacts of climate change on wheat yields in Northwestern Turkey. Agric Ecosyst Environ 141(1-2):112

Perez L, Rios DA, Giraldo DC, Twyman J, Blundo-Canto G, Prager SD, Ramirez-Villegas J (2019) Determinants of vulnerability of bean growing households to climate variability in Colombia. Clim Dev: $1-13$

Pesaran MH, Shin Y, Smith RJ (2001) Bounds testing approaches to the analysis of level relationships. J Appl Econ 16(3):289-326

Pickson RB, He G, Ntiamoah EB, Li C (2020) Cereal production in the presence of climate change in China. Environ Sci Pollut Res:1-12

Praveen B, Sharma P (2019) A review of literature on climate change and its impacts on agriculture productivity. J Public Aff 19(4):e1960

Qureshi MI, Awan U, Arshad Z, Rasli AM, Zaman K, Khan F (2016) Dynamic linkages among energy consumption, air pollution, greenhouse gas emissions and agricultural production in Pakistan: sustainable agriculture key to policy success. Nat Hazards 84(1):367-381

Rasul G (2021) Twin challenges of COVID-19 pandemic and climate change for agriculture and food security in South Asia. Environmental Challenges 2:100027

Raymundo R, Asseng S, Robertson R, Petsakos A, Hoogenboom G, Quiroz R, Hareau G, Wolf J (2018) Climate change impact on global potato production. Eur J Agron 100:87-98

Rehman A, Chandio AA, Hussain I, Jingdong L (2017) Is credit the devil in the agriculture? The role of credit in Pakistan's agricultural sector. The Journal of Finance and Data Science 3(1-4):38-44

Rehman A, Ma H, Irfan M, Ahmad M (2020) Does carbon dioxide, methane, nitrous oxide, and GHG emissions influence the agriculture? Evidence from China. Environ Sci Pollut Res 27(23):2876828779

Rehman A, Ma H, Ahmad M, Ozturk I, Chishti MZ, 2021. How do climatic change, cereal crops and livestock production interact with carbon emissions? Updated evidence from China. Environmental Science and Pollution Research, 1-12

Rivera-Ferre MG, López-i-Gelats F, Ravera F, Oteros-Rozas E, di Masso M, Binimelis R, El Bilali H (2021) The two-way relationship between food systems and the COVID19 pandemic: causes and consequences. Agric Syst 191:103134

Rosenzweig C, Elliott J, Deryng D, Ruane AC, Müller C, Arneth A, Boote KJ, Folberth C, Glotter M, Khabarov N (2014) Assessing agricultural risks of climate change in the 21st century in a global gridded crop model intercomparison. Proc Natl Acad Sci 111(9): 3268-3273

Sarker MAR, Alam K, Gow J (2014) Assessing the effects of climate change on rice yields: an econometric investigation using Bangladeshi panel data. Economic Analysis and Policy 44(4):405416

Shrestha S, Chapagain R, Babel MS (2017) Quantifying the impact of climate change on crop yield and water footprint of rice in the Nam Oon Irrigation Project, Thailand. Sci Total Environ 599:689-699

Sial MH, Awan MS, Waqas M (2011) Role of institutional credit on agricultural production: a time series analysis of Pakistan. Int $\mathrm{J}$ Econ Financ 3(2):126-132

Sossou S, Igue CB, Diallo M (2019) Impact of climate change on cereal yield and production in the Sahel: case of Burkina Faso. Asian
Journal of Agricultural Extension, Economics \& Sociology 37(4): $1-11$

Sultana H, Ali N, Iqbal MM, Khan AM (2009) Vulnerability and adaptability of wheat production in different climatic zones of Pakistan under climate change scenarios. Clim Chang 94(1-2):123-142

Tesfahunegn GB, Gebru TA, 2019. Climate change effects on agricultural production: insights for adaptation strategy from the context of smallholder farmers in Dura catchment, northern Ethiopia. GeoJournal, 1-14

Traore O, Chang W, Rehman A, Traore S, Rauf A, 2020. Climate disturbance impact assessment in West Africa: evidence from field survey and satellite imagery analysis. Environmental Science and Pollution Research, 1-17

Tripathi A, Tripathi DK, Chauhan D, Kumar N, Singh G (2016) Paradigms of climate change impacts on some major food sources of the world: a review on current knowledge and future prospects. Agric Ecosyst Environ 216:356-373

TRMAF, 2019. Republic of Turkey Ministry of Agriculture and Forestry, Crop production data. Available at https://www.tarimorman.gov.tr/ sgb/Belgeler/SagMenuVeriler/BUGEM. pdf.

TUBA, 2020. The report on climate change and public health in Turkey. Editors: Muzaffer Șeker, İsmail Koyuncu, İzzet Öztürk. Turkish Academy of Sciences Publications TÜBA Report No: 38

TUIK, 2020. Turkish Statistical Institute. Available at https://www.tuik. gov.tr/en

Ullah R, Shivakoti GP, Kamran A, Zulfiqar F (2016) Farmers versus nature: managing disaster risks at farm level. Nat Hazards 82(3): 1931-1945

Ullah A, Ahmad I, Saeed U, Ahmad A, Mahmood A, Hoogenboom G (2019) Climate smart interventions of small-holder farming systems. Climate Change and Agriculture, IntechOpen

United Nations (2020) The impact of COVID-19 on food security and nutrition (Policy Brief). United Nations, New York, NY

United Nations System Standing Committee on Nutrition, 2020. Food Environments in the COVID-19 Pandemic. https://www.unscn. org/en/newsevents/recent-news?idnews $=2040$

Vanli Ö, Ustundag BB, Ahmad I, Hernandez-Ochoa IM, Hoogenboom G (2019) Using crop modeling to evaluate the impacts of climate change on wheat in southeastern turkey. Environ Sci Pollut Res 26(28):29397-29408

Wang J, Vanga SK, Saxena R, Orsat V, Raghavan V (2018) Effect of climate change on the yield of cereal crops: a review. Climate 6(2): 41

Xie W, Huang J, Wang J, Cui Q, Robertson R, Chen K, 2018. Climate change impacts on China's agriculture: the responses from market and trade. China Economic Review

You L, Rosegrant MW, Wood S, Sun D (2009) Impact of growing season temperature on wheat productivity in China. Agric For Meteorol 149(6-7):1009-1014

Zaied YB, Cheikh NB (2015) Long-run versus short-run analysis of climate change impacts on agricultural crops. Environ Model Assess 20(3):259-271

Zakaria M, Jun W, Khan MF (2019) Impact of financial development on agricultural productivity in South Asia. Agric Econ 65(5): 232-239

Zewdie A (2014) Impacts of climate change on food security: a literature review in Sub Saharan Africa. Journal of Earth Science \& Climatic Change 5(8)

Zhai S, Song G, Qin Y, Ye X, Lee J (2017) Modeling the impacts of climate change and technical progress on the wheat yield in inland China: an autoregressive distributed lag approach. PLoS One 12(9): e0184474

Zhang T, Huang Y (2013) Estimating the impacts of warming trends on wheat and maize in China from 1980 to 2008 based on county level data. Int J Climatol 33(3):699-708 
Zhao C, Liu B, Piao S, Wang X, Lobell DB, Huang Y, Huang M, Yao Y, Bassu S, Ciais P (2017) Temperature increase reduces global yields of major crops in four independent estimates. Proc Natl Acad Sci 114(35):9326-9331
Publisher's note Springer Nature remains neutral with regard to jurisdictional claims in published maps and institutional affiliations. 